University of Nebraska - Lincoln

DigitalCommons@University of Nebraska - Lincoln

To Improve the Academy

Professional and Organizational Development

Network in Higher Education

1994

Creating Teaching and Learning Partnerships with Students:

Helping Faculty Listen to Student Voices

Helen Rallis

Follow this and additional works at: https://digitalcommons.unl.edu/podimproveacad

Part of the Higher Education Administration Commons

Rallis, Helen, "Creating Teaching and Learning Partnerships with Students: Helping Faculty Listen to Student Voices" (1994). To Improve the Academy. 318.

https://digitalcommons.unl.edu/podimproveacad/318

This Article is brought to you for free and open access by the Professional and Organizational Development Network in Higher Education at DigitalCommons@University of Nebraska - Lincoln. It has been accepted for inclusion in To Improve the Academy by an authorized administrator of DigitalCommons@University of Nebraska - Lincoln. 


\section{Creating Teaching and Learning Partnerships with Students: Helping Faculty Listen to Student Voices}

\section{Helen Rallis}

University of Minnesota, Duluth

Teaching effectively involves developing a partnership with our students based on mutual respect and trust. The first part of this paper provides a way in which we can initiate or further develop this partnership by inviting our students to tell us about themselves. Readers are shown how to become more aware of the diverse ways in which students learn and, hence, how to expand both teaching methods and content. The second part of the paper presents suggestions for facilitating a faculty development workshop on this topic. It shows how - by engaging in discussion with other faculty about our students' concerns-we can learn from each other and improve our teaching in ways that are stimulating and empowering for all involved and that take into account the changing needs of students, teachers, and the larger society.

Institutions of higher learning are enmeshed with numerous traditions, especially when it comes to the rituals that take place within the classroom. Students come to the hallowed halls to listen to learned professors; learned professors come to stand before the students and share their wisdom. Usually teaching takes the form of the lecturer standing behind a lectern, speaking from carefully prepared notes. 
Students listen and write as fast as they can, trying to capture as accurately as possible everything they hear. Later they study these notes carefully, attempting to memorize them so they can recognize them in a multiple choice selection or reproduce them as exactly as possible on the exam. When they do so, they feel they have learned well, and professors feel they have taught well. And so tradition goes on as it is supposed to. But is this as it should be?

In this paper, I will show how teachers can use student feedback as a powerful starting point for making changes in teaching, especially ones that take into account the diverse needs of our society. The first section of the paper examines the results of a three-year study of students' responses to the question "What are your pet peeves about college instructors?" and shows how to make changes in teaching based on student concerns, so that student needs can be better met. The second section describes how this study can be used in a faculty development workshop to guide college instructors in listening to the voices of their own students and, hence, in designing their courses and teaching to meet the needs of these students.

\section{Background}

My questions about U.S. higher education have been fueled by the writings of a number of educators who also have challenged the assumptions and practices inherent in the U.S. education system. Paulo Freire (1970) has been a critic of the way in which education has treated students as if they were empty slots waiting to be filled. $\mathrm{He}$ refers to this practice as "banking education" and argues that it disempowers people rather than teaching them to think. Dewey (1938) long ago argued that students learn best through active experiences. Glasser (1986) has stressed the need we all have, among other things, for some power or control over our lives. It is particularly important for teachers to acknowledge this need in order to build student ownership into their learning. Purkey and Novak (1984) extend this same concept, underscoring the importance of teachers creating learning environments that are inviting to all students so students will be willing and able to learn and ready to accept responsibility for their own learning. The notion of teaching to all students, not just to the top or 
even the majority, has received increasing emphasis as institutions of higher learning have shifted their thinking to be more inclusive of diversity.

As colleges and universities move into the twenty-first century, they are going beyond paying lip service to diversity issues and making diversity a high priority. If we truly value diversity and believe in the strength that comes from including diversity in our institutions and in our classes (both through what we teach and how we teach), then we must take the time to listen to the voices of the students who represent that diversity. The Old Golden Rule was "Do unto others as you would have them do unto you." This sounds noble, but the problem - or inherent value in this - is it implies that we know what is best for others. The conventional wisdom is if it was good enough for us, then it also must be good enough for our students. Furthermore, we believe it must be what they want us to do to them. This is at best misguided and at worst ethnocentric and paternalistic, ignoring the diversity that our students represent. If we are to embrace the value of diversity, we need to adopt the New Golden Rule of "Do unto others as they would have you do unto them." In order for us to apply this new rule, we need to find out what it is that our students want us to do and what they need in their particular circumstances. As an extension of this, we also need to find out what they do not want or need.

\section{Listening to what students say about college instructors}

Like most teachers, I have always made a point of having my students evaluate my course and my teaching at the end of each term. The problem has been that the students who give me the feedback are not around to benefit from the changes I make in response to their suggestions. Additionally, this practice has led me to assume that the changes desired by students from one class are necessarily what the next group of students wants. Yet, as all of us know who are involved in the business of teaching, each class has its own class personality, and each class is made up of unique individuals with different needs. Thus, what one class wants may not be what another wants. Recognizing this, I began using midpoint, formative course evaluations. 
While this did help me make adjustments to students' needs for the second part of the course, still I was not making the best use of the first half. Thus, in addition to the midpoint and end-of-course evaluations, I moved to a new approach in which I asked the students at the start of the class, before I taught them, to tell me about themselves and how they would like to be taught and treated.

Inviting students to tell me about themselves (see Appendix) has helped me understand them as individuals so I can treat them as they would like to be treated. On the first day of each quarter, students in all my classes are given a personal data sheet to complete right at the start of class, before I begin teaching. All I say to the students before they complete this sheet is that I would appreciate them responding to my questions so I can get to know them. The students' comments help me be more sensitive to their needs and avoid doing unnecessary and often unintentional things that bother them. In doing so, this helps me improve my teaching. I have found, too, that just asking these questions has helped create an inviting classroom environment and has encouraged students to be my partners in teaching and learning in an atmosphere of mutual respect. This sets the tone for the rest of the course. Over time, in analyzing the students' feedback, I noticed consistent patterns emerging in the responses to the question "What are your pet peeves about college instructors?" This led me to conduct a more formal analysis of their peeves, synthesizing the results to develop an overall picture of the responses. The results of this analysis are presented here.

For this study I used the surveys obtained from students in a secondary education methods course over a three-year period. The class is one of the first courses teacher education students take upon admission to the teacher education program. Students are either juniors, seniors, or postbaccalaureate students returning to college to receive their teaching licenses. The total number of students surveyed was 193 ( 86 men, 107 women) over a total of nine classes, with an average class size of 21.4 students. Students in this class have taken most of their liberal education and other lower division courses, and may have begun to take some upper division courses. The courses they have taken are primarily in the colleges of Liberal Arts, Education and Human Service Professions, Science and Engineering, and the School 
of Business and Economics at the University of Minnesota, Duluth campus, and at other colleges and universities from which some students have transferred. The courses that students have taken up to this point vary because students come from a range of fields, namely: sciences, math, social sciences, art, music, English, foreign language, health, physical education, and industrial education. Thus, their comments about college instructors are based upon experiences in a wide range of classes across their present and previous campuses.

\section{Results}

All the responses students gave to the question "What are your pet peeves about college instructors?" were written out verbatim. These were then organized into categories according to the content of the statement. For example, any comments specifically referring to instructors' poor teaching were placed into a category called "Poor organization/planning/teaching"; comments about teachers who lecture too much or are boring fell under "Lecture too much/boring." All comments having anything directly to do with teaching were then put into one large section on teaching; the next section included all comments on respect; the final section shows comments too disparate to be grouped under a single heading. The total number of comments in each category and section was then counted and is shown in Table 1. It should be noted that there are more responses than students, as some students listed more than one peeve. Thus, for example, where the table shows 25.4 percent of students giving a response about poor organization/ planning/ teaching, this means $25.4 \%$ of 193 students, or 49 students made a statement that fell into this category. Slightly more than forty-six percent of students, or 89 students in total, made comments in the broad section of teaching. Some of these same 89 students also made other comments that fell into other categories.

What is most striking about these results is the number of students making comments that fell into the two largest categories: "Teaching Techniques" and "Teachers' Lack of Respect." In the first category, $46 \%$ of students identified teachers' poor teaching or inadequate teaching. In this category, $25.4 \%$ of students made comments about poor organization and planning of presentations and courses, and poor 


\begin{tabular}{|c|c|c|c|}
\hline \multicolumn{4}{|c|}{$\begin{array}{l}\text { TABLE } 1 \\
\text { Summary of Student Responses to the question: } \\
\text { "What are your pet peeves about college instructors?" }\end{array}$} \\
\hline Response categories & $\begin{array}{c}\begin{array}{c}\% \text { of } \\
\text { students } \\
\text { with }\end{array} \\
\end{array}$ & $\begin{array}{l}\% \text { male } \\
\text { this respon }\end{array}$ & $\%$ female \\
\hline \multicolumn{4}{|c|}{ TEACHING } \\
\hline $\begin{array}{l}\text { Poor organization/planning/teaching } \\
\text { Lecture too much/boring } \\
\text { Grading expectations unclear } \\
\text { Lack of interest in subject/teaching } \\
\text { Unfair grading } \\
\text { Don't understand students' learning styles }\end{array}$ & \begin{tabular}{r|}
25.4 \\
6.7 \\
5.7 \\
4.7 \\
2.6 \\
1.0
\end{tabular} & \begin{tabular}{r|}
27.9 \\
10.5 \\
8.1 \\
3.5 \\
3.5 \\
1.2
\end{tabular} & $\begin{array}{r}23.4 \\
3.7 \\
3.7 \\
5.6 \\
1.9 \\
0.9\end{array}$ \\
\hline Total & 46.1 & 54.7 & 39.2 \\
\hline \multicolumn{4}{|c|}{ RESPECT } \\
\hline $\begin{array}{l}\text { Intellectual arrogance/talk down } \\
\text { Not approachable } \\
\text { Don't respect students } \\
\text { Feel need to control/impose views } \\
\text { Intolerant of students' questions }\end{array}$ & \begin{tabular}{r|}
15.0 \\
7.3 \\
6.2 \\
4.0 \\
2.1 \\
\end{tabular} & \begin{tabular}{r|}
18.7 \\
6.9 \\
4.7 \\
6.9 \\
2.3 \\
\end{tabular} & $\begin{array}{r}12.2 \\
7.5 \\
7.5 \\
1.9 \\
1.9 \\
\end{array}$ \\
\hline Total & 34.6 & 39.5 & 31.0 \\
\hline \multicolumn{4}{|c|}{ GENERAL } \\
\hline $\begin{array}{l}\text { Insensitive to students' time constraints (life } \\
\text { beyond class) } \\
\text { Go over class time } \\
\text { Not in during office hours/hard to get hold of } \\
\text { Don't relate material to real life } \\
\text { Too much busy work } \\
\text { Bias/sexism } \\
\text { No eye contact } \\
\text { Do as I say, not as I do } \\
\text { None } \\
\text { Other (no clear category) }\end{array}$ & $\begin{array}{r}7.3 \\
5.7 \\
5.2 \\
2.6 \\
2.6 \\
2.1 \\
2.1 \\
1.0 \\
4.7 \\
11.4\end{array}$ & $\begin{array}{r}3.5 \\
5.8 \\
4.7 \\
4.7 \\
3.5 \\
1.2 \\
0 \\
2.3 \\
6.9 \\
14.0\end{array}$ & $\begin{array}{r}10.3 \\
5.6 \\
5.6 \\
0.9 \\
1.9 \\
2.8 \\
3.7 \\
0 \\
2.8 \\
9.3\end{array}$ \\
\hline Total & 44.7 & 46.6 & 42.9 \\
\hline $\begin{array}{l}\text { Total \# of students: } \\
\text { ( } 9 \text { classes over } 3 \text { year period) } \\
\text { Total responses* }\end{array}$ & $\begin{array}{l}193.0 \\
242.0\end{array}$ & $\begin{array}{r}86.0 \\
(45 \%) \\
121.0\end{array}$ & $\begin{array}{l}107.0 \\
(55 \%) \\
121.0\end{array}$ \\
\hline
\end{tabular}


teaching in general. Almost half of the students focused on the importance of good teaching and said that it bothers them in particular when we are not organized. Students seemed to affirm what Freire (1970) argued: They do not want information "poured into them." They expect their teachers to be well prepared in their presentation of material and sensitive to the ways students learn. For example, students were peeved by teachers who "...teach the book word for word," "...teach the same way every day," or teachers who "...have forgotten how to teach."

As we recognize the diversity in our institutions, we say that we realize how important it is not just to acknowledge that this diversity exists but to respect it. Analysis of student comments, however, reveals that they do not feel we are doing this. Thirty-four-and-sixtenths percent made comments about teachers' lack of respect for students, intellectual arrogance, lack of approachability, and intolerance of student questions. Interesting to note here was the difference between the responses of males and females. Sixty-nine percent of males made specific reference to teachers needing to control students or impose their views compared with only $1.9 \%$ of females. Particularly significant was the fact that, without any prompting or prior discussion of what types of comments they could include in their pet peeves, $15 \%$ of students used almost the same words to describe their feelings about professors' intellectual arrogance. Some examples of students' words here were: "I hate it when they think they are much better than the students and talk above the class," "When they like to show they know more than the students, and don't give them the time to have an opinion."

If we believe in empowering students and respecting their diversity, in challenging them to be reflective, critical thinkers, then we need to rethink approaches that put ourselves on pedestals. Respecting diversity should not just be a passive response, but rather an active stand that we take. 


\section{Using student comments to make changes in our teaching}

After reading students' pet peeves, we can make immediate and specific changes in the content and the ways we teach. These changes enhance the learning experience for us all, students and teachers alike, without compromising academic excellence. I have found the more variety I include in the ways I teach, the higher the quality of work the students produce. They show greater insight not just into the basic course material, but into the perspectives of others as well. Some examples of changes I have made are as follows:

1. Organizing course material in more than one way, based upon my recognition that students learn differently: Some students benefit more from material that is organized in a logical, sequential way, while others prefer a holistic view that gives the big picture up front. Both of these preferences can be accommodated easily by clarifying the format of the syllabus. It can be presented not only in linear form (the standard form of what date, topic, assignments and readings), but also in a web/flow chart form that shows how the parts of the course and subtopics are connected. Additionally, it is valuable to refer back to the chart during the course so students can see how what they have done so far fits into the rest of the course.

2. Clarifying expectations about assignments: Assignment directions need to be written out, not just explained orally, and given at the start of the course so students who like to plan ahead can begin thinking about what they will need to do. What this means for us, as instructors, is that we have to think through very clearly what we expect from our students before we assign the work. It is not enough for us to have the broad expectation that they will understand the material. We need to decide what we want the finished product to look like and how we will grade it. There are different ways of developing these grading criteria. One is to have students cogenerate the criteria with the faculty in advance as he/she explains the assignment. Another is to share examples of past students' work, showing the class how the teacher graded the work. Thus, when we grade, we need to have specific expectations 
and criteria that we check rather than collecting assignments, looking at the variance, and only then deciding what is best. When the students do the work, they can use the criteria as a guide, instead of playing "guess what's on the teacher's mind." When the graded work is returned to them, they can compare it with the criteria and expectations that were laid out in advance and see exactly where they made mistakes. This empowers students so they feel they have earned the grade, rather than that we gave it to them.

3. Teaching in a variety of ways because students learn differently: Instructors need to make every effort to include a variety of learning modes in the course and in each class, every day. This means, for example, balancing linear and holistic organizational styles; teaching to auditory learners by explaining, to visual learners by showing, and to haptic/tactile learners by having them do or apply what they have learned. Some activities should allow students to work alone, and others to encourage collaboration and sharing of ideas (Gardner, 1993; Johnson and Johnson, 1984; Marzano, 1992).

4. Involving students in classes as much as possible: Regardless of how advanced the course material, students bring a variety of experiences and knowledge about any topic that is introduced. By inviting their comments and perspectives, and then by integrating these ideas into the content of the course, we give students ownership in what they learn. By paying attention to information they shared about themselves on their personal data sheets at the start of the course, we can build in examples that relate to their lives.

5. Incorporating sensitivity to students' lives outside of class: A key concern of students, especially women ( $10.3 \%$ of women), was instructors' insensitivity to students' time constraints outside of class. Being sensitive to these time constraints does not have to mean lowering expectations of students. Especially as funding for education is cut and increasing numbers of older than average age students attend colleges and universities, students face greater challenges in trying to balance their school work with outside responsibilities, such as earning money to pay for college and 
support their families. There are ways we can hold students to the standards we expect while being flexible about the ways and timelines they follow to achieve these expectations. I have found students do want to do the work I expect and are willing to put in the time and effort needed, but not necessarily within the framework specified. In order to help students balance the pressures of school with those in their personal lives, it helps to give plenty of advance warning about due dates and assignment guidelines, not just orally, but also in writing. Where possible, students should be allowed to negotiate restructuring of expectations to meet their needs (for example, taking an exam earlier or later because of a sick child). Often students don't need or want to be excused from work. What they do want is a respectful and sympathetic ear and someone who will help them work out how they can meet the expectations.

\section{Designing a faculty development workshop on Pet Peeves}

The results of this study can be used not just for individuals to read and reflect about on their own, but also as a springboard for discussion among faculty about how they teach and how they have made adjustments over the years to be more inclusive of their students. A powerful way to begin a workshop to get faculty to reflect on their own teaching and be willing to look at ways to make changes, is to have them examine their own experiences as students. Ask small groups of four or five to brainstorm their responses to the question, "What were your pet peeves about your college instructors?" As they do this, they should record their answers on poster paper or newsprint. What emerges in each group as they reminisce and laugh together, regardless of where or when they went to school, are a common bond and a realization of what they share. While these groups are talking, the faculty developer's role is to circulate among the groups, listening for common themes. It is important not to be drawn into any one group. Be willing to answer questions, but don't become part of the conversation. 
The next step in facilitating this workshop is to have each group post their list and, as a large group, compare the findings, searching for common themes. As these themes are generated, they are recorded on newsprint or a chalkboard by the faculty developer. The search for themes itself generates a whole new round of discussion and usually leads without any prompting to the next level of the workshop: What do we think our students' pet peeves are about us? It makes it so much easier to go to this next and harder level of looking at themselves. If the large group does not spontaneously move to discussing what their students think of them, the faculty developer should pose this question to them directly.

At this point, it is useful to hand out the survey results described earlier (see Table 1), give a brief background on how they were obtained or even give out a copy of the first part of this article, and examine systematically the different categories, comparing these with the faculty's own list from their experiences. Here the whole group examines why they, as teachers, inspire these peeves in our students and what we can do to respond. The key to successful reflection is in guiding participants away from being defensive to taking ownership of what they can reasonably change, balancing these with the realities of teaching in a college setting.

The final step in this workshop involves having participants develop a plan for what they will do with what they have learned. Together or individually they can generate questions to include on a personal data sheet to be given to their students. Depending on the group's needs, they may even want to have a follow-up workshop to share their results and design ways of responding to the students' comments.

\section{Conclusion}

Teaching effectively involves developing a partnership with our students based on mutual respect and trust. The first part of this paper has provided a way in which we can initiate or further develop this partnership by inviting our students to tell us about themselves. The second part of the paper presented suggestions for facilitating a faculty development workshop on this topic. It shows how, by engaging in 
discussion with other faculty about our students' concerns, we can learn from each other. The ultimate result from all of this interaction is a more meaningful learning and teaching experience that takes into account the changing needs of students, teachers, and the larger society.

\section{References}

Dewey, J. (1963). Experience and education (1st ed., 1938). New York: Macmillan.

Freire, P. (1970). Pedagogy of the oppressed. New York: Continuum.

Gardner, H. (1993). Multiple intelligences: The theory in practice. New York: Basic Books.

Glasser, W. (1986). Control theory in the classroom. New York: Harper and Row.

Johnson, D.W., \& Johnson, R.T. (1994). Learning together and alone: Cooperative, competitive, and individualistic learning (4th ed.). Needham Heights, MA: Allyn and Bacon.

Marzano, R. J. (1992). A different kind of classroom: Teaching with dimensions of learning. Alexandria, VA: Association for Supervision and Curriculum Development.

Purkey, W. W., \& Novak, J.M. (1984). Inviting school success: A self-concept approach to teaching and learning (2nd ed.). Belmont, California: Wadsworth. 


\section{APPENDIX 1 \\ PERSONAL DATA SHEET}

Name:

Student \#:

Phone:

Teaching area:

Indicate with an $\mathrm{X}$ which of the following courses you have completed. Indicate with a check those courses you are taking this quarter:

EdSe 3501

EdSe 5100

EdSe 5500

Special Methods class

I would appreciate it if you would take a few moments to answer the following questions about yourself. Feel free to include as much or as little as you want. If there are things about you that I have not asked, but which you would like me to know, please include these. My purposes in asking them are to help me get to know you and find out what interests you. This is important because I try to gear my course towards what will be of interest and value to you. Thank you!

1. Briefly tell me why you want to teach.

2. From what types of class activities do you learn most? (What is your preferred learning style?)

3. What are your least favorite types of class activities? 
4. What "pet peeves" do you have about college instructors?

5. What would you like to learn in this class? (Be as specific as you can.)

6. Tell me about yourself - for example: your outside interests, hobbies, any strong beliefs that you have that you'd like to share, what your plans are for your future, and anything else that will help me get to know you and make my teaching geared toward your interests. (Use back of this sheet if necessary). THANKS! 